Islamiconomic: Jurnal Ekonomi Islam

Volume 12 No. 1 January - June 2021

P-ISSN: 2085-3696; E-ISSN: 2541-4127

Page: 73 - 92

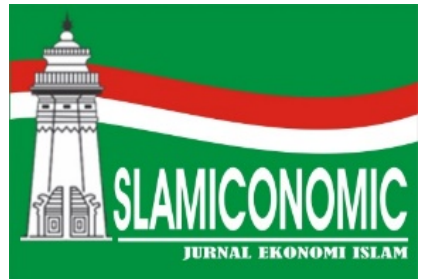

ISLAMICONOMIC: Jurnal Ekonomi Islam

Department of Islamic Economics

Faculty of Islamic Economics and Business

Universitas Islam Negeri Sultan Maulana Hasanuddin Banten

Jalan Jenderal Sudirman No. 30 Serang 42118

BANTEN - INDONESIA

Phone: +62254200323 || Fax: +62254 200022 || Website: www. journal.islamiconomic.or.id

\title{
SHARIA ACCOUNTING LITERATION AND FRAUDS PREVENTIVE ON FINANCIAL
} REPORTING IN SHARIA FINANCIAL INSTITUTIONS

\section{Asri Noer Rahmi}

\author{
STIE Indonesia Banking School, Jakarta, Indonesia \\ Corresponding author: asri.nr@ibs.ac.id
}

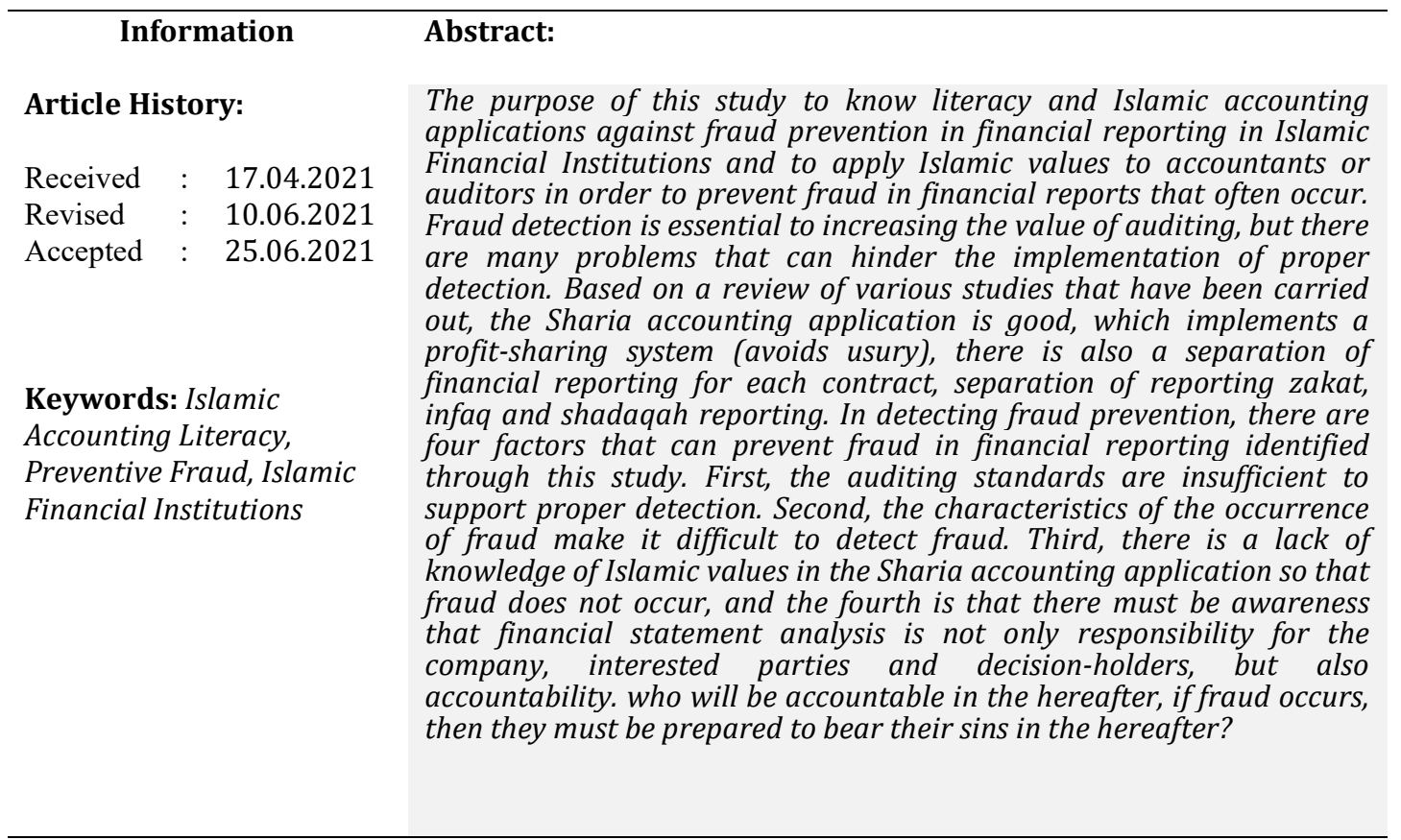




\section{A. INTRODUCTION}

The development of Islamic science is now increasingly widespread both inside and outside the country, as we know that Islamic science existed before the Prophet Muhammad was born and with the birth of the Prophet Muhammad, Islamic science is increasingly progressing where all the laws and regulations clearly refer to the Qur'an and sunnah. Where Islam as a universal religion means the rules, explanations, commandments, prohibitions and calls or suggestions that apply to the entire universe and its contents, including all human beings who are not limited to Muslims and until the end of the day (doomsday). later. Islam as a religion and a comprehensive or complete view of life can be shown by the verses of the Al-Qur'an which, when grouped, will regulate among others about aqidah, ethics, morals, worship and muamalah. Islam as a value system is a collection of items (values) that regularly interact or depend on each other to form a unique unit.

Today, most countries in the world have responded positively to developments and practices in Islamic economics, Islamic finance, and Islamic accounting. There have been many outside Islamic economists developing, researching and applying it (Chowdhury, 2005). Likewise in Indonesia there are many experts in the fields of Islamic economics and Islamic accounting. (Barbara, 2008; Hidayat, 2002; Isgiyarta, 2009, Muhamad, 2002; Triyuwono, 2000; Wiroso, 2008).

Islam also regulates the aspects and values of the accounting profession. Islam wants accounting not only to think about capitalist interests, not to think about the world, but also to be able to deliver all parties, including management, employees, investors, analysts and accountants to the safety and victory of the world and the hereafter (Harahap, 2008). Meanwhile, Triyuwono (2002) in Muhammad (2005) states that the entire Islamic tradition of ethics which is used as a business framework is built on the basis of Sharia. Sharia is a guideline used by Muslims to behave in all aspects of life. In Muslim societies, accounting is supposed to be influenced by an economic system which is governed by the philosophy that underlies the system. In contrast to secular Western philosophy as exemplified by Kant, where ethical emphasis is more on enlightenment rationality and belief. 
The world view of Islam does not only come from cultural and philosophical elements aided by science, but from one original source namely "the Qur'an and the Sunnah", confirmed by religion, and confirmed by intellectual and intuitive principles. (Abdur Rahman, 2003).

Islam as a religion and a comprehensive or complete view of life can be shown by the verses of the Al-Qur'an which, when grouped, will regulate including aqidah, ethics, morals, worship and muamalah. The pillars of Islam are aqidah, Sharia and morality. Aqidah as the foundation of human faith (tauhid) that animates Sharia (Islamic laws) and the rules regarding the morality of the people (akhlaq). Sharia underlies muamalah and worship. Muamalah is a human activity that concerns the relationship between humans and humans, animals, plants, earth, sea, air and other creatures of Allah SWT. (Wiyono, 2006).

In the practice of Islamic Accounting that is happening today, there are still many accountants who have not mastered or fully understood the concept and implementation of the Sharia Accounting application in the financial reporting that is presented, so that it can cause imbalance in the information presented in financial reporting because there are financial reporting unions such as zakat, infaq, shadaqah, qardh and others. Where the recording of Islamic accounting financial reporting is appropriate, namely the separation of accounts that have been regulated in PSAK 101. In addition, in financial reporting until now, there are still many frauds in the recording of financial statements that are presented.

\section{Image 1. Financial Reporting}

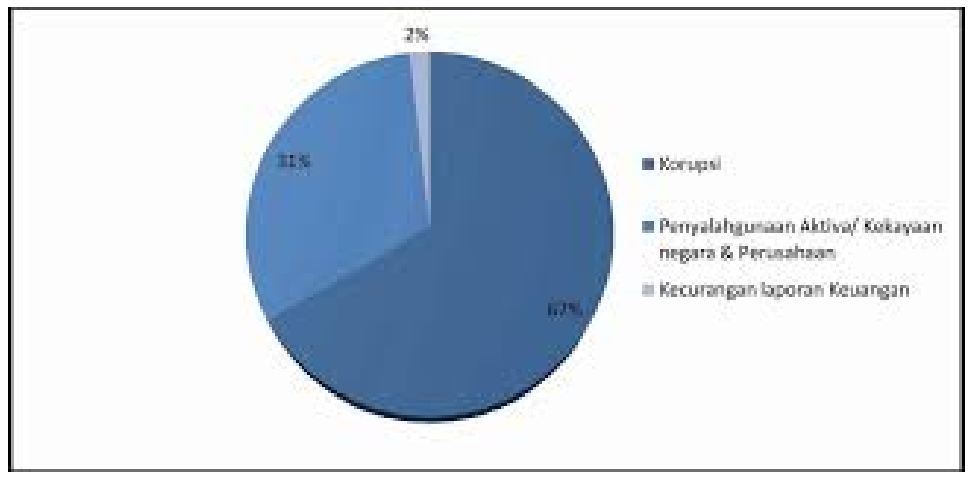

Source: ACFE Indonesia, 2016 
Islamiconomic: Jurnal Ekonomi Islam Vol.12 No.1 January - June 2021

Fraud is a latent danger that threatens the world. Research results from the Association of Certified Fraud Examiners (CFE) Global show that every year, on average, $5 \%$ of an organization's income becomes a victim of fraud to determine costs, frequency of incidents, methodology and various aspects of occupational fraud (work-related fraud). Currently, the perpetrators who commit fraud are not only limited to the upper class, but many have touched the lower layers of employees. This is certainly one thing that we all need to be aware of and care about in the surroundings where we work.

As we know that financial reports are a very important center of information because financial presentation and reporting is a determinant of the success or failure of a company or organization, both macro and micro. Financial reports are a decisionmaking tool in an organization or company; therefore, researchers intend to look at sharia accounting applications and Islamic values in preventing fraud that often occurs in financial reporting.

\section{B. LITERATUR REVIEW}

\section{Literacy Shariah Accounting}

Literacy word comes from the Latin "litera" (letter) which has a definition that involves mastering writing systems and conventions that accompany it. In this regard, Kern (2000) defines the term literacy comprehensively as follows: Literacy is the use of social, historical and cultural situations in creating and interpreting meaning through texts. Literacy requires at least an unspoken sensitivity about the relationships between textual conventions and the context in which they are used and ideally the ability to reflect critically about those relationships. Being sensitive to the aims and objectives, this literacy is dynamic, not static and can vary between and within communities and discourse cultures. Literacy requires a range of cognitive abilities, knowledge of deaf and spoken language, knowledge of genres and cultural knowledge.

Understanding literacy broadly in various fields, including understanding Islamic accounting. Literacy is related to knowledge, showing knowledge of one element that can influence various things on a person's behavior. In the Al-Qur'an Surah Al-An'am it has also been stated that knowledge or literacy is an important 
Asri Noer Rahmi: Sharia Accounting Literation...

requirement, so that every Muslim can distinguish what is allowed or prohibited in Islam (Purnomo et al: 2016). Romdhoni (2013) states that literacy is a social event that involves certain skills, which are needed to convey and obtain information in written form. OJK (2014) defines financial literacy as a series of processes or activities to improve knowledge, competence and skills of consumers and the wider community so that they are able to manage finances well.

Financial literacy is also related to how to manage limited financial resources in order to always feel qanaah, grateful and not lacking. (Irfan and Laily, 2016). The concept of financial literacy, which includes knowledge of financial concepts, the ability to understand communication about financial concepts, the ability to manage personal or company finances and the ability to make financial decisions in certain situations. (Dwitya Aribawa, 2016).

Accounting (accountancy) comes from the root word to account, which means "to count". Technically, accounting is defined as the process of recording, classifying, summarizing financial transactions measured in units of money, and reporting the results. (Mursyidi, 2003).

Sharia accounting according to (Harahap, 2001) is a new field in accounting studies developed based on Islamic values, ethics and Sharia, therefore it is also known as Islamic accounting. (Adiwarman, 2004) in his book explains that the development of accounting as a branch of social science has experienced a very basic and meaningful shift in values, especially regarding the underlying theoretical framework that is required to follow changes that occur in people's lives. So far, what is used as a construction theory of accounting is born from a cultural and ideological context. (Rifqi, 2008) describes the construction of conventional accounting into Islamic accounting (sharia) which is born from the cultural values of society and Islamic sharia teachings that are practiced in socio-economic life. Sharia accounting is seen as a social construction of Islamic society in order to apply Islamic economics in economic activities. Sharia accounting is a sub-system of the Islamic economic and financial system, used as a supporting instrument for the application of Islamic values in the realm of accounting. The main function of Islamic accounting is as a management tool that provides information to internal and external parties to the 
Islamiconomic: Jurnal Ekonomi Islam Vol.12 No.1 January - June 2021

organization. The concepts that underlie the preparation and presentation of Islamic financial statements for its users, namely:

1. Preparation of Sharia accounting standards, in carrying out their duties.

2. Preparation of financial statements, to overcome Sharia accounting problems as stipulated in Islamic Financial Accounting Standards (PSAK 101).

3. Auditor, in providing an opinion regarding whether the financial statements are prepared in accordance with the applicable Sharia accounting principles in PSAK.

4. Users of financial statements, in interpreting the information presented in financial statements that are prepared in accordance with Islamic financial accounting standards.

Parties that use Sharia financial reports in order to meet different information needs include:

1. Investors, need information to determine whether to buy, hold or sell an investment.

2. The donor of the qard fund, in relation to the decision making whether the qard fund can be paid upon maturity.

3. Owners of temporary syirkah funds, as information in making investment decisions with competitive and safe returns.

4. The owner of deposited funds, needs liquidity information related to deposited funds, whether it can be retrieved at any time.

5. Payers and recipients of zakat, infaq, alms and waqf as information on the source of the distribution of these funds.

6. Sharia Supervisor, has an interest in the compliance of the management party with Sharia principles.

7. Employees need information that shows the stability and profitability of the Sharia Institution. Employees also have an interest in assessing their ability to provide remuneration, retirement benefits and job opportunities.

8. Suppliers and other business partners, need information in deciding whether the amount owed will be paid when due.

9. Customers, have an interest in information regarding the sustainability of the Sharia Institution's business. 
Asri Noer Rahmi: Sharia Accounting Literation...

10. The government requires information to regulate the activities of Sharia entities related to tax policy determination and as a basis for compiling national income statistics and other statistics.

11. Society, Sharia financial reports as a provider of trend information, show the development of prosperity and the series of activities of Sharia Institutions.

Rifqi (2008) Parties with an interest in these financial statements can be specifically categorized as internal parties and external parties. Internal parties are parties that are directly related to the policies to be taken by the financial institution, such as investors and supervisors. Meanwhile, external parties that are not directly related to the policies to be taken by the financial institution, for example, are the government and the general public.

\section{Financial Statement Fraud}

Financial statement fraud can be defined as fraud committed by management in the form of financial statement misstatements that are detrimental to investors and creditors. This fraud can be financial or non-financial fraud. According to the ACFE (Association of Certified Fraud Examiner) corruption is part of fraud (Razee, 2010). Fraud is grouped into Corruption, Asset Misappration, and Fraudulent Statement. (Belkaoui, 2010). The fraudulent statement is a deliberate attempt to cheat by improperly compiling and reporting financial accountability, either with or without the use of accounting standards and techniques and adjusting non-financial transactions into financial statements. These efforts are usually designed with several concepts such as: the selective financial misrepresentation hypothesis, income smoothing, earnings management, creative accounting (creativity in accounting) and fraud accounting). Razaee (2010). International Standard on Auditing (ISA) divides fraud into only two major parts, namely misappropriation of assets such as theft or use of company assets for personal or group interests and fraud in financial statements (fraudulent financial statement and fraudulent financial reporting) in the form of manipulation of financial information with the aim of deceiving (intend to deceit) the users (stakeholders). Meanwhile, Certified Fraud Examiners (CFE) define fraud with the term corruption or bribery, which is an act of abuse of office for personal gain. 


\section{Sharia Financial Institutions (LKS)}

A Sharia Financial Institution is a financial institution whose operating principles are based on the principles of Sharia Islamiyah. Operations. Islamic financial institutions must avoid usury, gharar and maisir. These things are very forbidden and have been explained in the Al-Qur'an and Al-Hadith. Sharia Financial Institutions (LKS) according to the National Sharia Council (DSN) are financial institutions that issue Islamic financial products and that obtain operational permits as Sharia Financial Institutions. This definition emphasizes that an LKS must fulfill two elements, namely the element of conformity with Islamic Sharia and the element of legality of operation as a financial institution. The elements of conformity of an LKS with Islamic Sharia are centrally regulated by the DSN, which is manifested in various fatwas issued by the institution. The operating legality element as a financial institution is regulated by various agencies that have the authority to issue operating permits. Some of these institutions include the following:

1. Bank Indonesia as the institution authorized to regulate and supervise Commercial Banks and Rural Banks.

2. The Ministry of Finance as the institution authorized to regulate and supervise cooperatives.

3. The Office of the Minister of Cooperatives as an institution that has the authority to regulate and supervise cooperatives.

Some of the operational principles in the LKS are:

1. Fairness, namely the principle of sharing profits on the basis of actual sales based on the contributions and risks of each party.

2. Partnership, namely the principle of equality between the parties involved in cooperation. The position of customers (mudarib) investors (depositors of funds), and the use of funds, as well as the financial institutions themselves, are equal as business partners who work together to gain profit.

3. Transparency, in this case an LKS is required to provide financial reports openly and continuously to investor customers or the parties involved in order to know the true condition of the funds. 
Asri Noer Rahmi: Sharia Accounting Literation...

4. Universal, namely the principle whereby LKS are required to provide the same services regardless of ethnicity, religion, race and class to the community in accordance with Islamic principles as rahmatan lil alamin.

\section{The Role of Auditors and Efforts to Prevent Fraud}

As we know, the auditor is someone who is very influential on financial reporting, where in his activities the internal auditor is expected to contribute to the improvement of the entity's risk management, but it is also necessary to understand that not all entities have a risk management structure which is the responsibility of management, so the role of the internal auditor. assisting management through auditing, reviewing, evaluating, reporting and recommending the adequacy and effectiveness of the risk management process. Internal auditors have a role in helping ensure that management has carried out satisfactory corporate risk management. In connection with the role of the internal auditor in identifying and evaluating the significant risks faced by the company. In carrying out its duties, the internal auditor must pay attention to all the risks faced by the company in order to achieve its objectives.

In connection with the risks that may exist in the company, the duties of the internal auditor include; identify the risks to be faced, measure or determine the magnitude of the risk, look for ways to face and manage risks, formulate a strategy to minimize and control risk, which includes coordinating steps for the implementation of risk mitigation, and as well as evaluating the risk management program that has been made. So, it can be said that the auditor has at least 3 roles in fraud, such as; fraud prevention, fraud detection, and fraud investigation. In conducting an audit, the auditor will be faced with the possibility that the financial statements or management's accountability reports are intentionally prepared incorrectly, for the personal benefit of various members of management or management or other interested parties in a company unit. With various motives behind it, for example to cover up massive embezzlement of company assets or wealth.

Fraud prevention is generally an activity carried out by management in terms of establishing policies, systems and procedures that help ensure that the necessary actions have been taken by the board of commissioners, management and other 
Islamiconomic: Jurnal Ekonomi Islam Vol.12 No.1 January - June 2021

personnel in the company to be able to provide adequate confidence in achieving 3 main objectives, namely: reliability of reporting. finance, operational effectiveness and efficiency as well as compliance with applicable laws and regulations (COSO, 1992).

Dyreng, Mayew and Williams (2010) find evidence about the role of religion and social norms in corporate financial reporting in the United States. Managers of companies with high religious compliance show a smaller deviation from expectations, if there is a deviation, tend to increase the presentation into cash flow. In addition, companies that are located in areas of high religious compliance tend to reduce tax evasion activities (tax sheltering) and are more open to voluntarily disclosing bad news. McGuire, Omer and Sharp. Nathan (2011) revealed that religiosity reduces abnormal accruals, because there has been an increase in disclosure practices of earning management and accruals manipulation. It was also reported that religiosity increases financial reporting in companies with low external monitoring. Omer, Sharp and Wang (2013) have examined the relationship between religiosity with the decision to report going concerns in public accounting firms in metropolitan USA. The results show that non-big four auditor religiosity has an effect on business continuity disclosure on his audit opinion and has accurate bankruptcy predictions.

\section{METHODOLOGY}

The type of this research is a qualitative research. Sugiyono (2018) qualitative research method is a research method based on philosophy, which is used to examine scientific conditions (experiments) where researchers are instruments, data collection techniques in the analysis emphasize meaning. Qualitative methods aim to analyze and describe phenomena or research objects through social activities, attitudes and perceptions of individuals and groups. In qualitative research, researchers must have good communication skills in interviews and broad insight into the social environment that occurs and develops according to actual conditions or based on facts in the field (where the research was carried out). Researchers must be able to explain the results of interviews conducted, other data collection in research or phenomena from informant sources to explain why and how problems 
Asri Noer Rahmi: Sharia Accounting Literation...

occur. The population in this study is Islamic Financial Institutions such as Sharia Banks, BAZNAS, and BWI. The sample is part of the population that is a member of the population chosen to be used as research, the sample selection in this study is based on purposive sampling, namely. Sharia Financial Institutions registered with the Financial Services Authority (OJK).

\section{RESULT AND ANALYSIS}

Research Results and Discussion of Islamic Accounting Literacy Against Preventive Fraud Industry Financial institutions and banking are the industries most disadvantaged by fraud (ACFE Indonesia Chapter, 2019). In Islamic banks themselves, there are several cases which are of course detrimental to the bank concerned. For example, the fictitious credit case that occurred at Bank BJB Syariah in 2018 involving Acting President Director Yocie Gusman, thus significantly affecting bank operations and financial conditions. Although Islamic banks have special characteristics in the form of ICG which has the same principles as GCG in general, there are special principles, namely sharia compliance, but this does not guarantee that Islamic banks will be free from fraud.

\section{Image 2. Industry Fraud Impact}

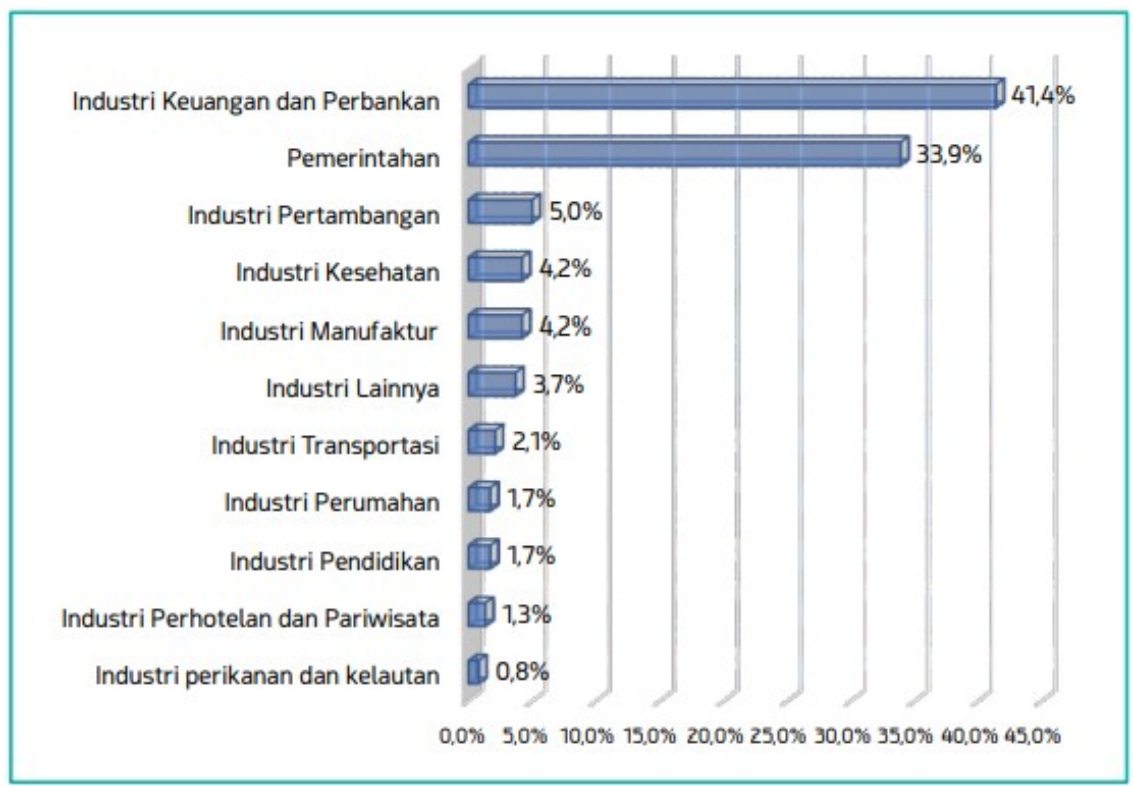

Source: Association of Certified Fraud Examiners (ACFE) Indonesia Chapter, 2019. 
Based on the results of interviews conducted in this study, the authors successfully interviewed the financial division of Islamic financial institutions as follows; Badan Amil Zakat Nasional (BAZNAS) BAZNAS has provided literacy and training related to Sharia accounting, but not all sections have received knowledge related to the Sharia accounting application in accordance with PSAK 101-109. Because BAZNAS is a Sharia financial institution that manages zakat, infaq, shadaqah and waqf funds in selecting and recruiting its staff, the most important thing is that they have basic knowledge of ziswaf literacy.

As it is known that the funds collected and distributed by BAZNAS are a mandate given by mustahik and people who entrust social virtue funds to BAZNAS, it is very necessary to have transparency and financial recording and reporting in accordance with Sharia financial reporting standards, so that financial reporting is can be accounted for both individually and by companies that entrust social funds to BAZNAS. In terms of financial reporting, BAZNAS is quite good, because it has a computerized financial reporting system and can be accessed through the baznas.org.id website. however, there is still a need for improvement in computerized systems and monitoring systems to prevent fraud in the financial statements presented.

The Indonesian Waqf Board (BWI) is a central Islamic financial institution that records and prepares financial reports from fundraisers of waqf institutions throughout Indonesia and distributes funds, both cash and non-cash, which must be given to waqf and waqf recipients, where the nazir is an intermediary that distributes waqf given by waqf. Where financial recording and reporting is very necessary for transparency and to facilitate the audit process that will be carried out routinely at the end of each fiscal year, based on this, literacy and training related to Sharia Accounting is needed at BWI, even though there has been literacy and training related to Sharia accounting applications, However, to update and resolve the issues that occur, it is felt that there is a need for support from all parties who have an interest in understanding financial reporting more deeply in order to be accountable for financial reporting in a transparent and trustworthy manner. For reported financial reporting, it is currently still using a manual system for financial reports, to prevent 
Asri Noer Rahmi: Sharia Accounting Literation...

fraud, a computerized system and a tidier financial arrangement are needed for disclosing financial statements.

Bank Mandiri Syariah (BSM) There is still a need for literacy and training related to fraud prevention. Because the Islamic Bank has a wide variety of financing products, services and other products to offer. Fraud is inevitable but can be minimized with the implementation of sharia compliance and Islamic government Sharia. Leaders, managers and supervisors are always reminded about the dangers and impacts of fraud and that's not all for all Islamic banks, they try to apply standards that comply with Islamic laws and regulations in their daily operations. It is undeniable that as a Sharia financial institution there must be fraud that occurs in the presentation of financial reporting, but by applying PSAK 101-109 which is the guideline for financial recording and reporting, at least it can minimize and can separate between halal and non-halal funds.

Bank BNI Syariah as we know that financial reports are an important factor in determining the success of a Sharia and non-Sharia financial institution. Regarding Islamic accounting literacy, it has been implemented by Bank BNI Syariah, but it is not intended for all existing staff and is only given to the financial division and accountants (internal auditors). Meanwhile, other staff are given literacy and training related to products owned by Sharia Banks and products that can be applied, either financing products, providing capital or service products. For Islamic financial reporting, it is in accordance with the standards of PSAK 101-109 and has used computerized financial reporting records so that it can be neat and organized.

Even though they have used a neat recording system, it turns out that there are still some who commit fraud even though it is very small. This shows a lack of literacy and awareness of staff who are still brave enough to commit fraud, so that it can provide losses not only individually and also to the Islamic financial institution itself. So, it is still necessary to have literacy and to instill Islamic values in the operations of Islamic banking in order to increase the responsibility and faith of all those involved and working in it, so that they are fully aware that every human being will be accountable for whatever has been done both from work and deeds and will accounted for not only in this world but also in the hereafter. 
Islamiconomic: Jurnal Ekonomi Islam Vol.12 No.1 January - June 2021

Bank Muamalat for Islamic financial reporting, it is in accordance with the standards of PSAK 101-109 and has used computerized financial reporting records so that it can be neater and more organized. Even though they have used a neat recording system, it turns out that there are still some who commit fraud even though it is very small. This shows a lack of literacy and awareness of staff who are still brave enough to commit fraud, so that it can provide losses not only individually and also to the Islamic financial institution itself. Fraud is inevitable but can be minimized with the implementation of sharia compliance and Islamic government Sharia. Leaders, managers and supervisors are always reminded of the dangers and impacts of fraud and that's not all for all Islamic banks, they try to implement standards that comply with Islamic laws and regulations in their daily operations. Therefore, as Muslims, we must remind each other and understand very well the impact and dangers of fraud which will cause harm to all parties and these losses may not only have an impact in the world but also cause damage in the hereafter, as we all know that Allah SWT is the best-good auditor.

Table 1. Sharia Banks xxx

Balance Sheet

During the month of January 20XX

\begin{tabular}{lclc}
\hline \multicolumn{1}{c}{ AKTIVA } & \multicolumn{2}{c}{ PASIVA } \\
\hline Cash & 500.000 & Liability & \\
\hline $\begin{array}{l}\text { Current accounts with } \\
\text { Bank Indonesia }\end{array}$ & 25.000 & Mudharabah Saving & 35.000 \\
\hline Other Funds BSI & 10.000 & Deposit Mudharabah & 25.000 \\
\hline $\begin{array}{l}\text { Accounts Receivable } \\
\text { Murabahah }\end{array}$ & 85.000 & ZIS Funds & 1.000 \\
\hline Financung Mudharabah & 20.000 & Deffered Profit Margin & 10.000 \\
\hline Financing Musyarakah & 30.000 & Non-Sharia Funds & 1.000 \\
\hline Advances for building rent & 10.000 & Amount of Liability & $\mathbf{7 2 . 0 0 0}$ \\
& & & \\
\hline Office supplies & 2.000 & & 5.000 \\
\hline Office equipment & 20.000 & Equity & 625.000 \\
\hline Total assets & $\mathbf{7 0 2 . 0 0 0}$ & Retained earning & 625.000 \\
\hline & & Capital Stock & 630.000 \\
\hline & & Total Equity & $\mathbf{7 0 2 . 0 0 0}$ \\
\hline
\end{tabular}


Asri Noer Rahmi: Sharia Accounting Literation...

From the table above, it can be seen that Islamic accounting, financial statements and profit-sharing calculations for Islamic Financial Institutions (LKS) use the basic concept of cash basis with the consideration of certainty of receipt and acknowledging that there is revenue sharing for something that is certain to be the right of income for LKS, because in the Al-Qur'an one knows for sure what tomorrow will take. In the Sharia accounting balance, there is a post of non-binding transfer obligation (ITT) which does not include obligations such as mudharabah deposits and mudharabah savings.

Ma'isyah as a cash concept is the basis for the Islamic cash flow statement. Ma'ísyah-based cash is related to the value-added value report of sharia, which is the value of cash flow to meet the profitability, solvency and flexibility of value-added sustenance (physical aspects) full of blessings (non-physical, both mental and spiritual) of the company. Profitability, solvency and flexibility of value-added provision must clearly have a correlation with the principle of submission (halal, thoyib and usury-free). Ma'ísyah is also used to provide information when there is insufficient information on adding sharia and working capital. Insufficient information is related to the application of cash-based principles, both in determining the added value of sharia and capital structure (sharia balance sheet).

\section{Fraud Prevention Analysis of Accounting in Islamic Perspective and The View of Islam Against Fraud}

Islam is a sacred religion that was revealed by Allah SWT to be a human guide in every activity carried out in all aspects of life from social, political, economic, educational and others. There are several things that are in the spotlight and the current trend, namely: replacing the economic interest system with profit sharing system (free interest) and optimizing the zakat system in the economy (income redistribution function). With the implementation of profit sharing and zakat systems in the economy it is hoped that they can help to become a system that instills Islamic values and can reduce fraud and can help the growth of an Islamic-based economy. This is the moral that underlies every ethical formation of a Muslim in giving an appreciation of ownership and wealth (Badroen and Suhendra, 2006) Islam is very resistant to all acts of fraud Because in principle it becomes harm that will harm all 
Islamiconomic: Jurnal Ekonomi Islam Vol.12 No.1 January - June 2021

parties, the objectives of the five Islamic Shari'a are: preserving religion, life, reason, descent and wealth. Fraud (cheating) is a form of crime that is similar to fraud and is a crime that can harm many people and can influence decision making. In accounting this crime is very subtle and can be seen in plain view of course this is the same as the crime that appears, only in its subtle realization because in the form of financial reporting.

Discussion of Accounting in the Al-Qur'an in the modern world, it has recognized how important and needed accounting is in the business world (Freeman, et al., 1973). According to Meige and Meigs (1991) accounting is the language of business, this reason is quite accepted because accounting is very useful as a basis for business decision making. (Fess and Warren, 1989). In the Al-Qur'an chapter 17 verse 36 it is stated:

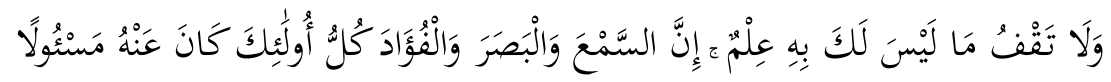

"And do not you follow anything that you do not have knowledge (professional) about (accounting), because actually hearing, sight and heart, all will be held accountable."

Al-Qur'an surah Al-Baqarah verse 282 has recommended recording when carrying out economic transactions actually has a very high urgency value, the existence of recording can be used as evidence (black and white), using witnesses for material transactions is very necessary because It is feared that certain parties will renege on the agreements that have been made, and of course a comprehensive financial reporting system will strengthen management because all transactions can be controlled properly so as to avoid leakage or fraud. Profits that are recorded correctly will be able to help fulfill their zakat obligations as has been recommended by Allah in Surah Al-Baqarah verse 43: The existence of accounting has the aim of creating justice and avoiding disputes for the parties who carry out transactions. (Widodo, 1999). Bookkeeping accompanied by explanations and witnesses of all financial economic activities based on evidence in the form of: invoices, notes, receipts, receipts or notarial deeds (which always use sanctions) for transactions with a high materiality value and a relatively greater possibility of dispute. In certain 
Asri Noer Rahmi: Sharia Accounting Literation...

circumstances sanctions can be replaced by bookkeeping records that have a legality function (as long as these documents are legally valid).

In Hamka's interpretation in Tafsir Al-Azhar Juz 3 Surat Al-Baqarah verse 282 which states several things that are relevant to accounting (Al-Muhasabah), how important and obligatory it is to maintain writing (economic transactions) because it is not always the parties who are transacting that they live long, even though debt the debt is still not paid off, the heirs may deny because evidence is not found and if the evidence is needed in the future, the attorney is required to have documents that can be accounted for because the smallest transaction is always recorded, it is very clear and must be understood as an order (mandatory) because it is very relevant and important in making economic decisions for the needs of economic development at present and in the future.

The coherence of the verses of the Al-Qur'an Al-Baqarah verses 275-281 explains that: Allah explains the law of usury and its consequences for people who eat usury and in order to avoid usury it is recommended to pay zakat, and have a relationship to pay zakat with the correct calculation (nishab), it is necessary to calculate (record) assets, debts, capital, income and expenses from business (economic activities) correctly as well. The connection with the next paragraph mu'amalah economic transactions can also be carried out in transit and this requires recording and proof so that one day they want to collect sufficient evidence or that the goods were carried for the value of the merchandise that was left behind. This linkage further clarifies that the objective of Sharia accounting is to present financial reports correctly in order to obtain accurate information as the basis for calculating zakat. Another purpose of Islamic accounting is as written evidence that can be accounted for at a later date. The final message in the above verse is: " fear Allah, Allah will teach you and Allah is All-Know everything."

Accounting in Arabic is called Muhasabah, there are 48 times it is mentioned in the Qur'an. Muhasabah has 8 definitions: 1) Yahsaba which means to count, to compute or measure or to measure, 2) Also has the meaning of recording and counting one's actions continuously, 3) Hasaba is complete responsibility, 4) Interpreted to be neutral, 5) Tahasaba means guarding, 6) Trying to get, 7) Expecting the treasures in the hereafter, and 8) Make attention or account for. 
Islamiconomic: Jurnal Ekonomi Islam Vol.12 No.1 January - June 2021

Religious values come from Allah SWT, regulating the relationship between humans and their Gods, humans and humans and humans with their environment. Religious values tend to be absolute, regulating obedience to a prosperous life and disobedience to a miserable life, both in this world and after death. This reply motivates people to control their behavior in accordance with the guidance laid down by religion. Therefore, humans as God's creatures naturally adhere to values that originate from their Creator, namely religion. Because all religions aim to realize the highest value of human life, namely eternal life in the hereafter. The values of worldly life are not a final goal, but only a temporary goal, as a medium to achieve the final goal, namely eternal life in the hereafter. (Agoes and Ardana, 2013).

\section{E. CONCLUSION}

Based on the results of research that has been done, the Islamic accounting application is in fact quite good, because the purpose of the Sharia accounting application is to avoid uncertainty and prohibition of usury. Islam rejects and does not justify all acts of cheating because in principle it becomes a condition that will harm all parties, the five objectives of Islamic law: to maintain religion, soul, mind, descent, and property. Another moral value, states that all the material in this world belongs only to Allah SWT, a human being only serves as a caliph. Maintain material ownership and develop a halal path. Basically, in pursuing material ownership, Islam stipulates that all forms of transactions are basically permissible, except for those prohibited by sharia. Islam has a system in running the wheels of the economy, there is a system of mudarabah, inan, abdan, wujuh and mufawadah. it can be concluded that the Islamic accounting application in Indonesia is quite good. It's just that there are still many accountants or auditors in financial institutions who do not understand sharia accounting in accordance with PSAK 101 concerning Islamic Financial Reporting that applies in Indonesia, nor do all of the accountants or auditors understand the need to instill Islamic values in making Islamic financial reporting. which have been set. Accounting in Arabic has the meaning of counting and measuring, which means a person's actions continuously until the afterlife court and through the scales as a measurement tool and Allah SWT as the accountant. 


\section{F. REFERENCES}

Al-Quran dan Terjemahannya. (2009). Departemen Agama RI. Jakarta: Sygma Examedia Arkanleema.

Adiwarman Karim (2004). Bank Islam Analisis Fiqih dan Keuangan, Jakarta: PT. Raja. Grapindo Persada.

Anindita Wahyu A (2013). Persepsi Akuntan Tentang Penerapan PSAK No. 101 Pada BMT di Kabupaten Klaten. Skripsi Keuangan Islam. Fakultas Syariah dan Hukum, Universitas Negeri Yogyakarta.

Andri, Soemitra (2014). Bank dan Lembaga Keuangan Syariah, Jakarta: Kencana. Cet. Ke-4, h. 452.

Bank Indonesia. (2008). Kodifikasi Produk Perbankan Syariah. Jakarta: Bank Indonesia.

Barbara, A. (2008). Akuntansi Perbankan Syariah. Naskah Pelatihan, TOT Perbankan Syariah, Kerjasama Direktorat Perbankan Syariah Bank Indonesia dengan STAIN Kudus, 28 Agustus.

Choudhury, M. A. (2005). Islamic Ekonomics and Finance: Where Do They Stand? 6 ${ }^{\text {th }}$ International Conference on Islamic Economics, Banking, and Finance, 21-24 November, Jakarta, Indonesia.

Direktorat Perbankan Syariah: "Konsep Dasar Perbankan Syariah" Bank Indonesia, Naskah Pelatihan, TOT Perbankan Syariah, Kerjasama Direktorat Perbankan Syariah Bank Indonesia dengan STAIN Kudus, 28 Agustus.

Harahap, S.S., Wiroso, Yusuf.M. (2007). Akuntansi Perbankan Syariah Edisi Revisi Tahun 2007. Jakarta: LPFE Usakti

Harahap, S.S. (2007). Teori Akuntasi Edisi Revisi Tahun 2007. Jakarta: Rajawali Press.

Hertanto, Widodo Ak, dkk, (2000). Panduan Praktis Operasional Baitul Mal Wal Tamwil (BMT), Bandung: Mizan,

Hidayat, N. (2002). Urgensi laporan keuangan (akuntansi syariah) dalam praktik ekonomi Islam. Simposium Nasional I: Sistem Ekonomi Islam. Proceedings, 1314 Maret, Yogyakarta, Indonesia.

Ikatan Akuntan Indonesia (2009). Pernyataan Standar Akuntansi Keuangan No.101111 (Akuntansi Syariah). Jakarta: IAI 
Islamiconomic: Jurnal Ekonomi Islam Vol.12 No.1 January - June 2021

Isgiyarta, J. (2009). Kerangka Konseptual Akuntansi Syariah: Proses Pencarian Bentuk. Naskah Kuliah, MAKSI-UDIP.

Muhamad (2002). Penyesuaian teori akuntansi syariah: perspektif akuntansi sosial dan pertanggujawaban. Simposium Nasional I: Sistem Ekonomi Islam. Proceedings, 13-14 Maret, Yogyakarta, Indonesia.

Naimah dan Ridwan (2014). Analisis Implementasi Akuntansi Syariah di BMT Kudus. Jurnal Iqtishadia, Vol. 7, No. 1, Maret 2014.

Richa Rosiyanti (2013). Analisis Penerapan Akuntansi Syariah di KSU BMT AMAN UTAMA Jepara. Skripsi. Fakultas Ekonomi dan Bisnis, Universitaas Nahdlatul Ulama Jepara.

Rifqi Muhammad (2008), Akuntansi Keuangan Syariah Konsep dan Implementasi PSAK Syariah, P3EI Press, Yogyakarta.

R. Sanjaya Silalahi (2012). Analisis Penerapan PSAK 101 Pada Laporan Keuangan Koperasi Syariah BMT Al-Ittihad Rumbai, Pekanbaru. Fakultas Ekonomi dan Ilmu Sosial, Universitas Islam Negeri Sultan Kasim.

Sri Indiarti (2017). Fungsi Akuntansi Syariah pada BMT-BMT di Tangerang Selatan. Prodi Akuntansi, Universitas Pamulang Tangerang.

Sugiyono. 2018. Metode Penelitian Kuantitatif Kualitatif dan R \& D. Bandung: Alfabeta The Accounting and Auditing Organization for Islamic Financial Institutions (AAOIFI). (2004) Accounting, Auditing and Governance Standards for Islamic Financial Institution's. Bahrain, AAOIFI

Triyuwono, I. (2002). Sinergi oposisi biner: formulasi tujuan dasar laporan keuangan akuntansi syariah. Simposium Nasional I: Sistem Ekonomi Islam. Proceedings, 13-14 Maret, Yogyakarta, Indonesia.

Wiroso (2008). Konsep Perbankan Syariah: Komparasi Bank Syariah dan Bank Konvensional.

Naskah Pelatihan, TOT Perbankan Syariah, Kerjasama Direktorat Perbankan Syariah Bank Indonesia dengan STAIN Kudus, 28 Agustus.

Wulandari, S., \& Suganda, A. D. (2021). Determining factors of earnings management based on accrual model. Jurnal Akuntansi dan Auditing Indonesia, 25(1). 